\title{
Lessons of the Financial Crisis for the Design of National Pension Systems
}

\author{
GARY BURTLESS
}

CESIFO WORKING PAPER No. 2735

CATEGORY 3: SOCIAL PROTECTION

JULY 2009

Presented At CESifo Venice Summer Institute, July 2009

\footnotetext{
An electronic version of the paper may be downloaded

- from the SSRN website:

www.SSRN.com

- from the RePEc website:

- from the CESifo website:

www.RePEc.org

www.CESifo-group.org/wp
} 


\title{
Lessons of the Financial Crisis for the Design of National Pension Systems
}

\begin{abstract}
The recent financial crisis and historical record suggest important lessons about the design of national pension systems. First, wide fluctuation in asset returns makes it hard for wellinformed savers to select a saving rate or a sensible investment strategy for DC pensions. Workers who follow identical investment strategies but who retire a few years apart can receive DC pensions that are startlingly unequal. Second, it is hard for ordinary workers, as opposed to optimal planners, to make sensible choices about portfolio allocation. Their investment errors mean that actual returns fall short of the theoretical returns that could be earned by a well-informed, disciplined investor.
\end{abstract}

JEL Code: J32, H55, G11, J33.

Gary Burtless

The Brookings Institution

John C. and Nancy D. Whitehead Chair in Economic Studies

1775 Massachusetts Avenue

NW, Washington, DC, 20036

USA

gburtless@brookings.edu

July 21, 2001, second draft

This paper was prepared for the CESifo conference on "Rethinking the Privatization of Social Security" held in Venice, Italy, July 10-11, 2009. The opinions expressed are the author's alone and do not reflect the views of CESifo or the Brookings Institution. 


\title{
Lessons of the Financial Crisis for the Design of National Pension Systems
}

\author{
by \\ Gary Burtless \\ THE BROOKINGS INSTITUTION \\ Washington, DC USA
}

THE TOPIC OF THIS CONFERENCE is "rethinking social security privatization.” In view of recent events, it is natural to begin rethinking by considering the lessons of the financial crisis for the design of national pension systems. The lessons I discuss are not new ones. They are old lessons, ones we could have inferred from economic theory, practical experience, and financial market history known before the crisis began.

The first lesson is widely recognized in the finance literature, and it was vividly demonstrated by asset price movements in the past year. Asset prices and real returns are highly uncertain in capitalist economies. They fluctuate widely and unpredictably from one year to the next, from one decade to the next, and from one quarter century to the next. Over a long time horizon, investors can usually expect to obtain better returns if they accept greater year-to-year variability in returns. This empirical regularity does not offer any guarantees, however. Over investment horizons that are relevant to retirement investing, the range of observed historical returns is quite wide. The range is so wide, in fact, that it is hard for optimal planners to decide how much of their salaries to set aside for retirement consumption, assuming they want to enjoy stable annual consumption over their late working careers and retirement.

A second lesson of the crisis is that it is even harder for ordinary human beings, as opposed to optimal planners, to make this kind of decision and then stick to it. Unlike optimal planners, ordinary humans face problems of self control when trying to devise and follow through on a long-term saving plan. Mandatory saving, either in private or public pension plans, can help solve the self-control problem. In contrast to most public pension plans, many private plans put decisions about portfolio allocation in the hands of individual workers. Most humans have only a rudimentary grasp of basic financial economics, however. They may be aware that some kinds of investments, like corporate equities, are subject to greater price fluctuation compared with other assets, like bank deposits and short-duration bonds. But most workers are probably unaware of differences across asset classes in expected rates of return over 20- or 40- 
year investment horizons. Furthermore, their investment decisions may be excessively influenced by the recent trailing returns of different asset classes.

The behavior of professional investment managers is better informed and more disciplined than that of ordinary humans. Recent financial history reminds us of a third lesson, however. The decisions of professional managers are also subject to serious error, including many kinds of error identical to those committed by ordinary humans. When investment professionals manage assets owned by other, less sophisticated investors, their behavior is naturally affected by self interest. If investment professionals have an outsize influence in determining their own compensation contracts, the contracts will frequently reward investment behavior that is not in the best interest of investors. Of course, far-sighted and well-informed investors will reject such contracts and seek out managers offering compensation terms that closely align the interests of managers and investors. Unfortunately, far-sighted, well-informed investors are greatly outnumbered by ordinary humans (see lesson \#2 above). Ordinary humans typically place their savings in the hands of investment managers who receive compensation under performance contracts that reward them for short-term performance but fail to penalize them when short-term gains are later reversed by large-scale losses. The asymmetry of this reward structure is advantageous for investment managers but not in the interests of people whose funds are invested.

These lessons of the financial crisis have direct implications for the role and regulation of private, worker-controlled retirement investment accounts in a nation's pension system. Such pensions have important advantages, as has been noted by advocates of social security privatization. The buildup of funds in individual retirement accounts can boost private and national saving. For most workers the relationship between contributions and ultimate retirement benefits is much more transparent in the case of individually owned investment accounts than it is in traditional public pension systems. The transparency and simplicity of the relationship between contributions and benefits may reduce the labor supply distortions induced by a pension system.

The financial crisis reminds us, however, that the pensions payable under a private investment account system are highly variable from one year to the next unless workers invest in a very conservative portfolio. Optimistic estimates of workers' expected returns under private retirement accounts almost always assume that workers hold a sizeable percentage of their 
portfolios in risky assets. If they make this investment choice their pensions will be very unpredictable even under optimistic assumptions about their self-discipline in maintaining a consistent and prudent investment strategy. Recent evidence suggests that many if not most worker-investors are far less well-informed and self-disciplined than assumed in the standard economic model, which implies that the risk-adjusted returns actually obtained by workers will fall short of the theoretical returns implied by standard financial theory. The assumption that fund managers acting as agents of the worker-investors will act solely in the interests of retirement savers is hard to reconcile with the actual behavior of fund managers (Bebchuk and Fried 2003 and Bebchuk 2009). This is another reason that unregulated or lightly regulated retirement investment accounts can produce risk-adjusted returns that are well below returns that are implied by financial market history.

In the remainder of the paper I briefly describe some of the recent debate over social security privatization and consider in detail the historical evidence on the variability of pensions financed out of individual investment accounts. This evidence is based on observed returns on major U.S. asset classes over the period from 1872 through 2008. In other papers I have considered the variability of returns in individual account pensions for worker-investors in other industrial countries (Burtless 2003 and 2007). On the whole, the variability of hypothetical pensions is lower for workers in the United States than it is for workers in other industrialized countries. The policy implications of these results therefore also extend to most other industrial countries. I next consider evidence on the actual financial knowledge and investment behavior of retirement savers. The paper ends with a short discussion of policy implications for national pension design.

\section{Background}

The goals of a national pension system are to assure secure and adequate incomes to workers whose earnings have been reduced as a result of invalidity or old age and to assure adequate incomes to the surviving dependents of deceased workers. Economists emphasize that these goals should be achieved through programs that are affordable and that preserve incentives for able-bodied people to work throughout their careers. Some also stress that the programs should not interfere with the goal of maintaining adequate national saving. In recent years governments and international organizations have focused on designing or reforming national pension systems so they can be kept affordable in the long run. 
For many rich and middle-income countries, population aging is a major stimulus for reform. The projected budget costs associated with population aging are so large that governments have been or will be forced to make major changes in the structure of their pension systems. In the past two decades policymakers in a number of rich countries have shown interest in following the example of Chile, which replaced its public, pay-as-you-go pension system with a private system organized around individual investment accounts. Advocates of this kind of reform point to Chile's success in introducing a private account system to replace a failing and under-funded public system, a system the government began phasing out in the early 1980s. In the past three decades, Chile's private pension system has received high marks for sound administration, good returns, and broad political acceptance. (It has, however, received lower marks because of major holes in workforce coverage.) The expected surge in public retirement costs in rich industrialized countries has made many economists and some policymakers receptive to the idea of a Chilean-style private substitute or supplement to existing unfunded public systems.

The World Bank spurred interest in this kind of reform in the early 1990s when it published Averting the Old Age Crisis (World Bank 1994). The book advocated a three-pillar national pension system. The first proposed pillar would provide basic, defined-benefit (DB) pensions, funded out of current payroll or income taxes, and it would assure minimally adequate incomes to the covered population. This component of the system would be mandatory and publicly managed. A second mandatory but privately managed system would collect earningsrelated contributions from the covered workforce and deposit them in individual, definedcontribution (DC) pension accounts. The accounts would be publicly regulated but privately managed. Pensions financed out of the accounts would be fully funded, possibly contributing in the early years of reform to a higher national saving rate. The third pillar of the suggested system would provide workers with a structured vehicle for retirement savings in addition to the savings mandated by the first two pillars of the system. This component would be voluntary and privately managed. The first pillar of the system would be explicitly redistributive in favor of the poor and other disadvantaged groups, and the first two pillars of the system would provide critical lifecycle insurance to workers and their dependents. In many, though not all, rich countries adoption of the three-pillar system recommended by the World Bank would entail a substantial shift toward a more funded and more privately managed social security system. 
In 2001 the World Bank published a second volume on national pension systems entitled New Ideas about Old Age Security (Holzmann and Stiglitz 2001). This volume reconsidered and extended the analysis in Averting the Old Age Crisis. The leading chapter, by Peter Orszag and Joseph Stiglitz, argues against the idea that a privately managed, defined-contribution pension program is the most sensible way to organize the funded portion of a national pension system (Orszag and Stiglitz 2001). A key point of their analysis is that many of the supposed advantages of private, defined-contribution pensions over public systems are based on unrealistic comparisons between an ideal, efficiently managed private system and existing public retirement programs. This kind of comparison sheds no light on the inherent advantages and disadvantages of the two kinds of system. If a private, defined-contribution system were actually implemented, it would fall short of the ideal envisioned by proponents. Similarly, the shortcomings of existing public, defined-benefit retirement programs are not necessarily inherent in such systems. Instead, they might be the result of policy mistakes that can be easily remedied.

Proponents of defined-contribution pensions frequently argue, for example, that such pensions provide superior labor supply incentives, because they do not distort the marginal relationship between a worker's pension contributions, on the one hand, and expected pension benefits, on the other. This claim depends crucially on the returns workers expect to obtain on their pension contributions. In countries with imperfect capital markets, it is conceivable that workers assign very low probability to their chances of obtaining positive or even zero returns on their DC pension contributions. In extreme cases, their contributions may be viewed as equivalent to a pure tax on earnings. In most existing public, defined-benefit systems, there is a gap between workers' marginal contribution and the marginal gain they can expect in the form of higher future benefits. This gap is not inherent in DB plans, however, since benefit formulas can be reformed to strengthen the link between contributions and expected future pensions.

\section{Variable returns and funded pensions}

The financial crisis has reminded many workers of the uncertainty of returns on private savings. Workers whose retirement savings were mainly invested in corporate equities, real estate, or corporate bonds have sustained heavy losses over the past year. In most countries, stock market losses have exceeded 35 percent of the investor's holdings at the start of last year. In some countries, losses in major asset classes have exceeded 50 percent. The effect of these kinds of losses on labor supply incentives is not always easy to assess. The wealth losses will 
almost certainly encourage later retirement among workers who had large DC wealth holdings when the crisis began. On the other hand, workers who are compelled to make minimum annual contributions into a DC plan may scale back their assessment of the future payoff from such contributions. It is hard to see how this reassessment of the value of mandated pension contributions has an effect that differs materially from the effect of increasing the tax on labor compensation. The efficiency differences between contributions to DB and DC pension accounts, whether publicly or privately managed, are easy to exaggerate.

The government can sponsor and manage either DB or DC plans, and both types of plan can be either funded or unfunded. Typically, of course, governments offer unfunded DB plans. Similarly, private employers can offer their employees either DB or DC plans. In the United States an important distinction between privately sponsored DB and DC plans is the identity of the party that bears the risk of asset market fluctuations. If an employer offers a DB plan, the employer must pay promised benefits to covered workers, regardless of the returns on the pension fund's portfolio. Employers bear the risk of financial market fluctuations. If an employer offers a DC plan, it is responsible for making promised contributions into each worker's retirement account but it bears none of the risk of financial market fluctuations. When investments held in a worker's account earn poor returns, the worker will accumulate a small nest egg and obtain a small pension.

Much of the public discussion of the U.S. financial crisis has focused on the misfortune of older workers enrolled in DC plans. This is understandable, both because their problems are obvious and because well over half of private-sector employees in the U.S. who are enrolled in a private pension plan are covered solely by a company-sponsored DC plan. Only 10\% of enrolled private-sector workers are covered solely by a DB plan. In the recent past, however, companysponsored DB plans were much more important. In 1979, 62\% of pension-covered privatesector workers were enrolled solely in a DB plan and another 22\% were enrolled in both DB and DC plans. Even though private DB plans are now less important than they were in the past, they remain economically significant because they are offered by so many large, high-compensation employers.

The recent financial market turmoil has exposed the risks of company DB plans, both to employers and to employees. The future pension liabilities of such plans are funded under a variety of assumptions about average future returns in different asset classes, expected employee 
tenure under the plan, and the life expectancy of pensioners. When the trailing returns on plan assets are high, employers make small contributions or no contributions at all to their plans. When trailing returns are low, many plans face a serious underfunding problem. Unfortunately, periods in which trailing returns are low tend to have two other characteristics: Nominal bond yields are also low, and company bankruptcy rates are high. When bond yields are low, the cost of purchasing annuities for newly retired workers is high. DB pension plans need more funds per worker to pay for anticipated future liabilities. Unfortunately, the level of assets in the fund has declined because recent returns on those assets have been low or negative. The combination of low asset valuations and high annuity prices makes the firm liable for higher pension contributions, often at a time when economy-wide demand for its products is low. Increased funding obligations for the DB plan may in fact help push the company into bankruptcy. Since 1974 the U.S. government has provided pension insurance to workers enrolled in companysponsored DB plans. The insurance has important limitations, however. Workers of bankrupt firms who are owed large pensions or who are younger than 65 may receive insurance coverage for only part of their promised pensions. As this discussion shows, the financial market risks of corporate DB plans are shared in a very complicated way by sponsoring companies, their employees, and the government. Since the division of risk is far from transparent, the impact of the financial crisis on DB pensions has received much less attention than the impact on workers who are enrolled in DC plans. It seems likely, however, that the crisis will contribute to a further erosion in the popularity of company DB pension plans.

It is worth reflecting on the reasons why one country - the United States - originally adopted a publicly managed retirement system in the 1930s. The recent dive in stock prices and home values offers a reminder of why government-guaranteed pensions seemed like such a good idea in the Great Depression. President Franklin Roosevelt proposed creation of social security in 1935, a bit more than five years after the stock market crash of October 1929. Between the end of 1928 and the end of 1932, U.S. stock market prices fell 71\%. Even if we make allowances for reinvested dividend payments and the drop in the price level, the real value of the composite stock portfolio fell almost 55\%. The collapse of stock prices and the bankruptcy of thousands of farms, businesses, and banks wiped out the savings of millions of retirees and older workers. Many industrial and trade union pension plans became insolvent, leaving covered pensioners and older workers without a dependable source of old-age income. Given these shocks, it cannot be 
surprising that the president, Congress, and most voters thought a public pension plan, backed by the taxing power of the government, was preferable to sole reliance on private retirement savings.

\section{Figure 1.}

\section{U.S. Stock Market Prices, 1950-2009:II}

S\&P stock index (deflated using 2000 prices)

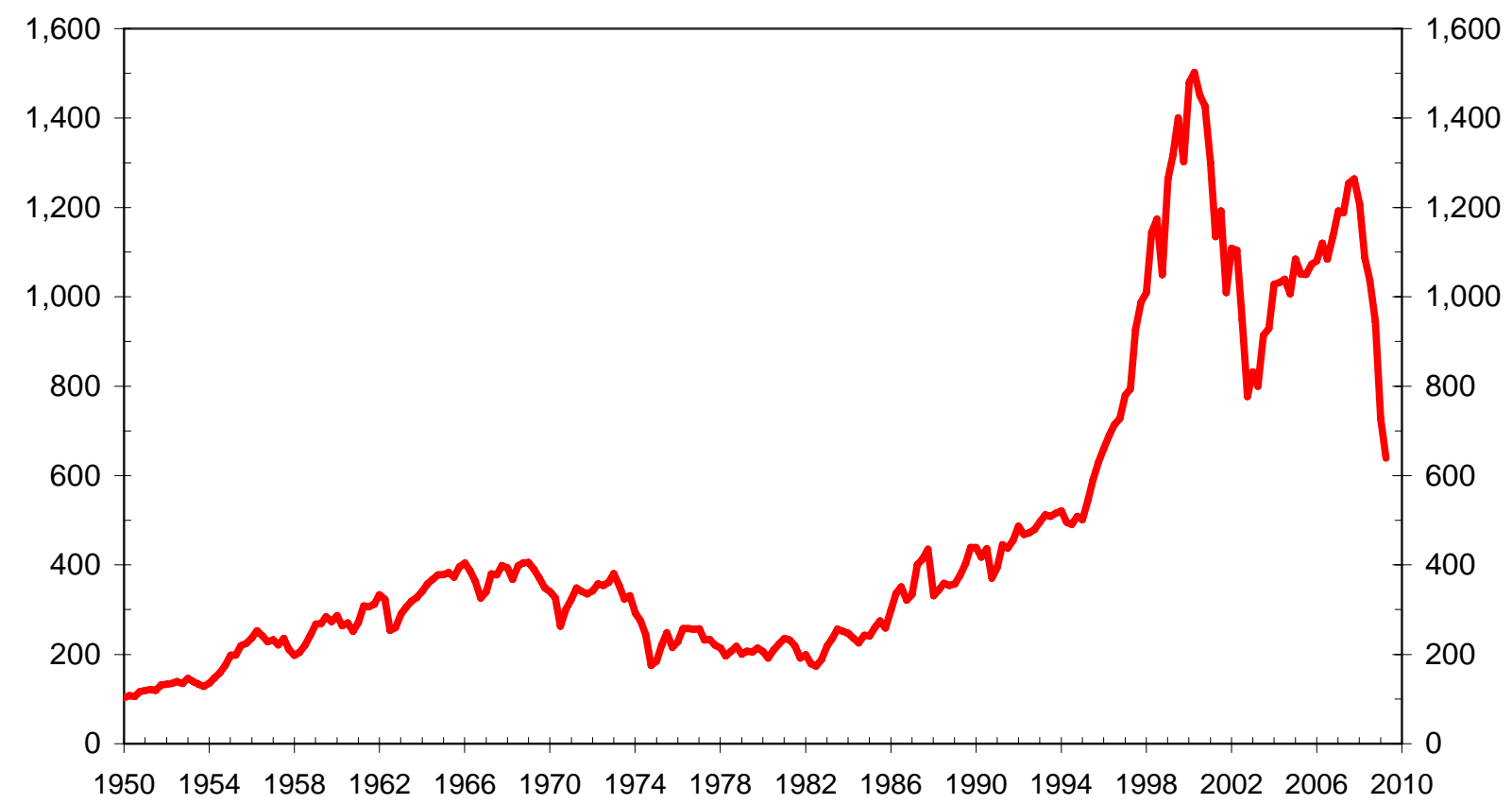

Source: Standard and Poors composite stock index.

The current U.S. social security system covers a bigger percentage of the workforce and offers better income protection than the one established in the Great Depression. Like the original system, however, the current program provides workers with a reliable source of retirement income that is largely insulated from the risks of company bankruptcy and financial market turbulence. The performance of capital markets in 2008 reminds us why voters in the 1930s shifted their allegiance from private to public management of retirement savings. Between the end of 2007 and the end of 2008, the Standard and Poors composite stock index fell $38.5 \%$. Including reinvested dividends and adjusting for the change in consumer prices, the total real return on U.S. stocks in 2008 was $-37.1 \%$ (see Figure 1). Newly retired workers who had invested all their savings in the stock market saw the purchasing power of their nest eggs shrink 
by more than a third. Americans who invested part of their savings in smaller capitalization stocks or in foreign equities did even worse. About two-thirds of American households own the dwellings in which they live. U.S. home prices started to fall in 2007, and the decline accelerated in 2008 (see Figure 2). Many homeowners have sizeable mortgages on the homes they occupy, so the drop in their net home equity was, in percentage terms, much faster than the drop in home prices.

Figure 2.

\section{Index of Real U.S. House Prices, 1975-2009:I}

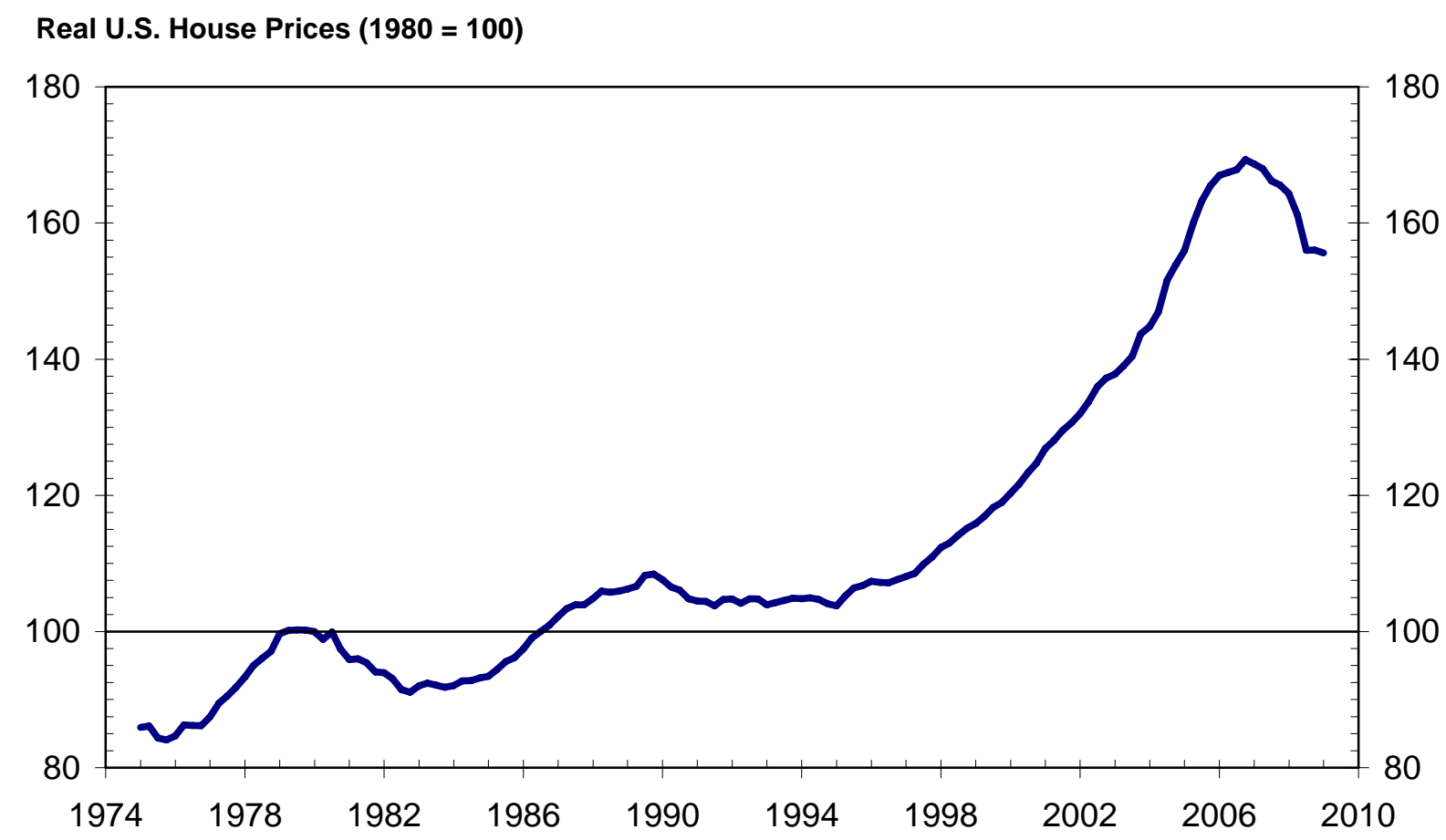

Sources: Federal Housing Finance Agency and U.S. Department of Commerce, Bureau of Economic Analysis. Note: Federal Housing Finance Agency index of U.S.-average house price deflated using GDP deflator.

Plunging stock prices and falling home values sharply reduced the net wealth of U.S. households (see Figure 3). The ratio of household net worth to household disposable income fell from 6.4 in the second quarter of 2007 to 4.7 in the first quarter of 2009. Although the current wealth-income ratio is not low by historical standards, the large losses in household wealth will have a profound effect on older workers and retirees who largely depend on private assets to support their retirement consumption. The sharp drop in wealth will make it difficult for older workers to afford retirement and for current retirees to maintain their previous consumption. 
In contrast to the performance of most private assets, the inflation-adjusted value of social security benefits was essentially unaffected by the 2008 financial crisis. Social security pensions are not totally secure, of course. If the U.S. Congress does not raise the contribution rate or scale back social security benefits sometime in the next 30 years, the reserves of the system will be depleted by about 2040. At that point social security pensions will have to be cut or contributions increased. If all of the adjustment takes the form of a benefit reduction, which is the outcome mandated by current law, monthly pensions will have to be cut about $22 \%$.

\section{Figure 3.}

\section{Ratio of Net Household Wealth to Household Disposable Income, 1952-2009:I}

Net wealth I Income ratio

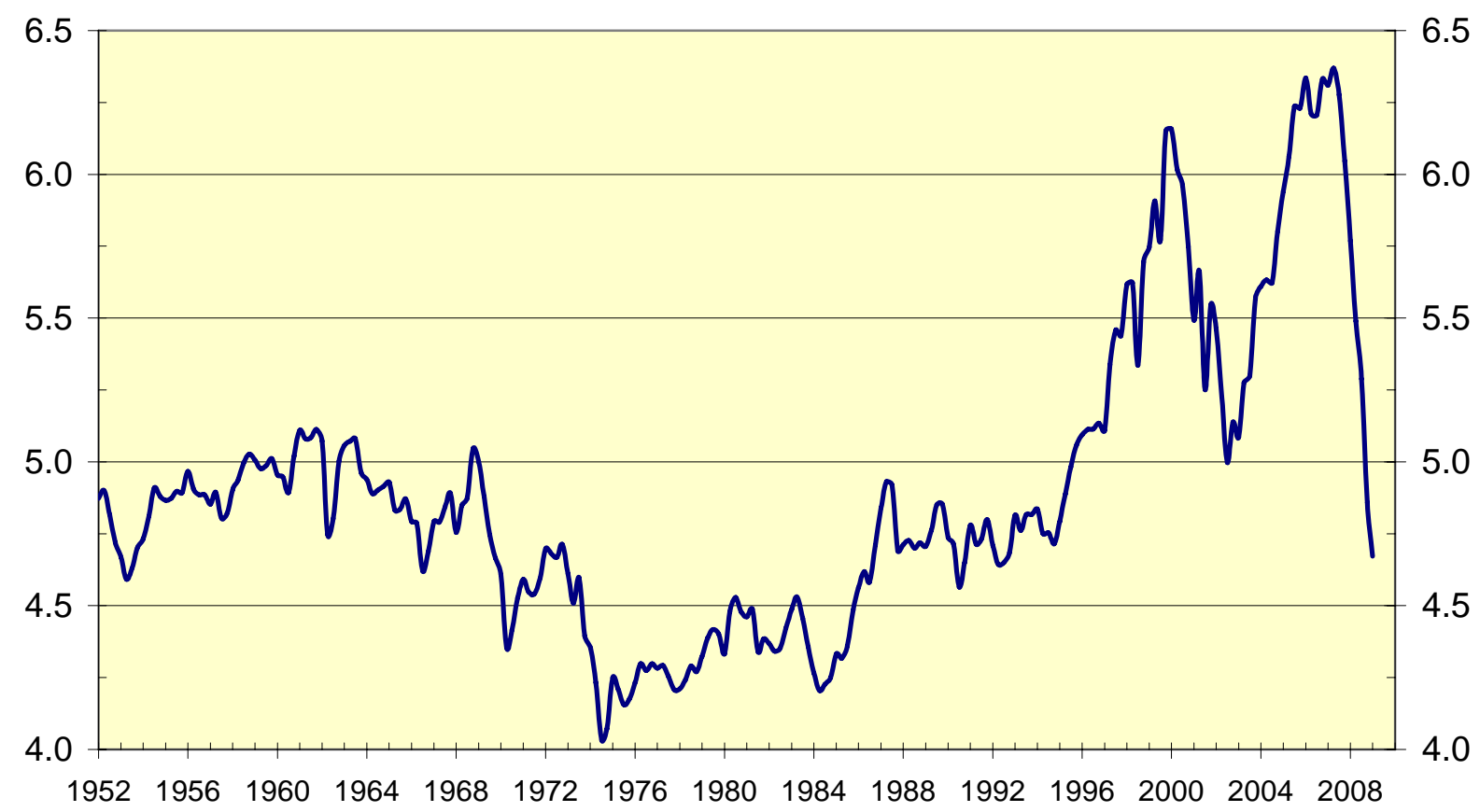

Sources: Board of Governors of the Federal Reserve System, Flow of Funds

The long-run funding problem of social security is one reason critics argue for full or partial privatization of the system. In 2005 President George W. Bush urged Congress to adopt a reform plan that would allow U.S. workers to divert some of their social security contributions into private retirement accounts. The reform would have undercut social security funding because workers who opted into the new accounts would send smaller contributions to the existing system. Since social security’s revenue base would be smaller, Congress would 
eventually be forced to reduce monthly pensions or make large transfers from the U.S. Treasury to assure that the system will not become insolvent.

Individual account plans like the one proposed by President Bush differ from traditional social security in an obvious way. Each worker's private retirement benefit depends solely on the size of the worker's contributions and the success of the worker's investment strategy. Workers who make bigger contributions and earn better returns on their savings will receive larger pensions than workers who contribute less and earn lower returns. In contrast, workers' social security benefits depend on their average lifetime wages, their eligible dependents when they claim a pension, and the age at which a benefit is claimed. Workers who retire at the same age and with the same earnings records generally receive very similar benefits, regardless of the year in which they claim a pension or the current level of asset prices.

A claimed advantage of individual retirement accounts is that they permit workers to earn a much higher rate of return than can be obtained on contributions to a fully mature, pay-as-yougo public pension program. I have heard it claimed, for example, that workers can expect to earn negative rates of return on their contributions to social security, while they can earn $6 \%$ or more on their contributions to a private retirement account. The comparison is incorrect and seriously misleading. ${ }^{1}$ Most U.S. workers can expect to obtain positive real returns on their contributions to social security. Over the next few decades, only a small fraction could obtain significantly higher returns if the U.S. public pension system were partly or fully privatized.

Market fluctuations and the value of pensions. A basic problem with individual retirement accounts was highlighted by the recent market turmoil. It is hard to predict how much retirement income will be produced by a private savings plan or DC pension account. The value of assets held in the account can fluctuate widely unless all the savings are held in very

\footnotetext{
${ }^{1}$ Three problems make the comparison misleading. First, the claimed return on social security contributions is too low. Some American contributors will earn negative returns on their social security contributions, but on average future returns are expected to be between $1 \%$ and $1.5 \%$, even if contributions must be raised or benefits reduced in order to eliminate the program's funding shortfall. Second, workers will not have an opportunity to earn the stock market rate of return on all their retirement contributions, even if Congress establishes an individual account system. Workers' overall rate of return on their contributions to the retirement system will be an average of the return obtained on their contributions to individual accounts and the return earned on their contributions to whatever remains of the traditional social security program. For most people who are currently at work or who will join the workforce in the next three decades, the combined rate of return will be much closer to the current return on social security contributions than it will be to $6 \%$. Finally, the claimed $6 \%$ return on stock market investments includes no adjustment for the large standard deviation around the expected return. A meaningful comparison of returns would show risk-adjusted returns of the two kinds of contributions. The return on stocks looks much less favorable under this kind of comparison.
} 
conservative government-issued securities. Of course, if retirement savings are invested in very safe assets, workers cannot anticipate receiving a high rate of return. In July 2009, for example, the real annual yield on newly issued 10-year Treasury Inflation Protected Securities was 1.92\%. If these bonds are held for their full 10-year term, investors will receive a return on their investment that corresponds to the rate of consumer inflation plus a little less than $2 \%$. Other kinds of savings instruments, like corporate stocks and bonds, offer higher expected returns, but they are not guaranteed to produce a positive or even a zero rate of return after adjusting for inflation.

Figure 4.

Replacement rate obtained from personal account savings of workers who invest solely in stocks and contribute $4 \%$ of annual salary over a 40 -year career

\section{Replacement rate}

(Annuity / Final wage)

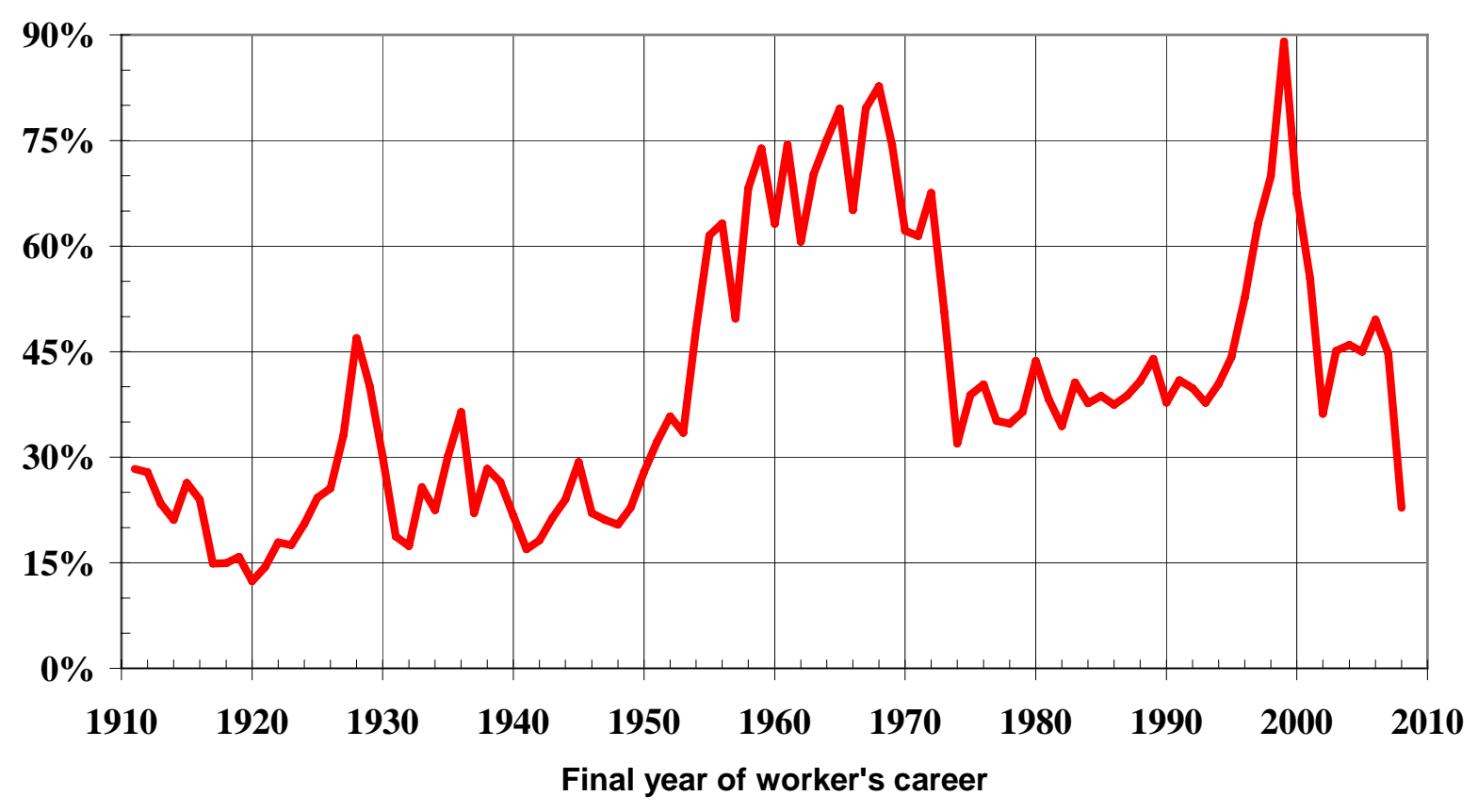

Source: Author's calculations as explained in text.

All private investments and most public securities are subject to risk. Over long periods of time, investments in the U.S. stock market have outperformed other types of U.S. financial investments, including Treasury securities and corporate bonds. This explains financial advisors' recommendation to young and middle-aged workers that they should hold much of their retirement savings in stocks. But as last year's markets reminded us, stock returns are highly 
variable from one year to the next. They are substantially more variable over short periods of time than are the returns on safer assets, like short-term Treasury securities and insured certificates of deposit.

Many critics of traditional social security seem to believe the annual ups and downs in the stock market average out over time, assuring even the unluckiest investor a good return if he or she invests steadily over a full career. A moment's reflection shows that this cannot be true. From the end of December 2007 to the end of December 2008, the value of the Standard and Poor's composite stock index fell almost 39\% after adjusting for changes in the U.S. price level. Shares purchased before December 2007 lost almost four-tenths their value in less than twelve months. For a worker who planned on retiring at the end of 2008, the drop in stock market prices would have required a drastic cut of planned retirement consumption if the worker's sole source of income was derived from stock market investments.

Figure 4 shows calculations of the pensions that workers could expect under an individual account plan using information about annual investment returns, interest rates, and inflation dating back to 1872. I start with the assumption that workers enter the workforce at age 22 and work for forty years until reaching their 62nd birthdays. I also assume they contribute 4\% of their wages each year to their individual retirement accounts. Wages typically rise through workers' careers until they reach their early or mid fifties, and then earnings begin to fall. When workers reach age 62, I assume they use their retirement savings to purchase a single-life annuity. A standard measure of the value of an annuity is the replacement rate, which is simply the amount of the monthly annuity expressed as a percentage of the worker's final wage. ${ }^{2}$

\footnotetext{
${ }^{2}$ I assume that the age profile of earnings in a given year matches the age profile of earnings for American men in 1995 as reported by the Census Bureau. In addition, I assume that average earnings in the economy as a whole grow 1.5\% a year. While it would be interesting to see how workers' pensions would vary if we altered the percentage of contributions invested in exotic assets, in my calculations I assume that all contributions are invested in some combination of U.S. stocks, long-term U.S. government bonds, and low-risk, short-term commercial paper or 6-month certificates of deposit. The total return calculation for stocks is based on the return for the Standard and Poor's composite stock index; the total return calculation for bonds reflects the return on U.S. government debt with a maturity of at least ten years. For years up through 1997 the total return on safe 6-month securities is based on the yield on commercial paper published by the Federal Reserve; for years after 1997, when the Federal Reserve series was discontinued, the safe short-term total return is calculated from the yield on 6-month certificates of deposit. Interest and dividend payments from the worker's investment portfolio are immediately reinvested in the same security, and the worker's portfolio is rebalanced at the end of every year to achieve a planned percentage distribution of stock, bond, and safe short-term investments. I assume that workers incur no expenses buying, selling, or holding stocks, bonds, and safe short-term securities, which biases upward estimated rates of return. When workers reach their 62nd birthdays, they use their asset accumulations to purchase a single-life annuity for males. (Joint survivor annuities for a worker and a spouse would be about one-fifth lower than the ones shown in the charts.) To determine the annuity company’s charge for the annuity, I use the Social Security Actuary's projected-
} 
Figure 4 shows replacement rates for workers who invest all their retirement savings in U.S. equities. I track replacement rates for workers retiring at the end of successive years from 1911 through 2008. The hypothetical experiences of ninety-eight workers are shown in the chart. The worker who entered the workforce in 1872 and retired at the end of 1911, for example, would have accumulated enough savings in his individual retirement account to buy an annuity that replaced $28 \%$ of his peak lifetime earnings (that is, his average earnings between ages 54 and 58). The worker who entered the workforce in 1967 and retired at the end of 2006 could have purchased an annuity that replaced $50 \%$ of his peak earnings. The highest replacement rate (89\%) was obtained by a worker who entered the workforce at the start of 1960 and retired at the end of 1999. The lowest (12\%) was obtained by a worker who began to work in 1881 and retired in 1920. Nine-tenths of the replacement rates shown in the chart fall in the range between $16 \%$ and $75 \%$. The average replacement rate is $40 \%$. For workers retiring after 1945 , the replacement rate has averaged $49 \%$.

The main lesson to be drawn from the chart is that individual retirement accounts invested solely in the stock market offer a very shaky foundation for a secure retirement income. Workers with the good fortune to retire when stock prices are high obtain big pensions, while workers with the bad luck to retire after a market crash can be left with a very meager retirement income. The largest pension shown in the chart is more than seven times bigger than the smallest one. Even in the years since 1960, the experiences of retiring workers have differed dramatically. The biggest pension was almost four times the size of the smallest one. In the six years from 1968 to 1974, the replacement rate fell fifty-one percentage points, plunging from 83\% to 32\%. In the six years from 1993 to 1999, it jumped fifty-one percentage points, soaring from 38\% to 89\%. In the twelve months from December 2007 to December 2008, the predicted replacement rate dropped eighteen percentage points, falling from $45 \%$ to $23 \%$, the smallest replacement rate in more than fifty years.

life table for males reaching age 65 in 1995. The annuity company is assumed to invest solely in long-term U.S. government bonds, so when it determines the price of an annuity, it uses the current yield on long-term government bonds. I assume that the annuity company sells a fair annuity. It does not earn a profit, incur administrative or selling costs, or impose extra charges to protect itself against the risk of adverse selection in its customer pool. These assumptions are unrealistic. Annuity companies typically charge an amount that is between $10 \%$ and $15 \%$ of the selling price of annuities to cover these items. My assumptions therefore yield an overly optimistic estimate of the pension that each worker would receive. For a more detailed explanation of the calculations, see Burtless (2003). 
U.S. social security pensions have been far more predictable and have varied within a much narrower range. The Social Security Actuary estimates that workers with an average lifetime earnings profile will receive an inflation-adjusted monthly pension that replaces $42 \%$ to $46 \%$ of their late-career earnings. Workers with lower-than-average earnings receive higher replacement rates (Clingman, Nichols, and Chaplain 2008, p. 3). Compared with most forms of private savings, traditional social security provides a more predictable basis for retirement planning and a much more reliable foundation for basic retirement income

Strategies to reduce retirement income risk. The calculations shown in figure 4 refer to the experiences of workers who consistently invest $4 \%$ of their wages in U.S. equities. This investment strategy has on average yielded the best pension available to most U.S. workers. Workers who do not want to accept the risks of equity investment can put some or all of their savings in less risky assets, such as corporate or U.S. Treasury bonds or very safe short-term securities. Figure 5 shows replacement rates when workers invest part or all of their retirement savings in U.S. government bonds. Under one of the alternative investment strategies, workers place half their savings in long-term government bonds and the other half in stocks. Under the less risky strategy, they invest all their savings in government bonds.

As can be seen in the chart, workers who choose a less risky investment strategy will experience less variability in replacement rates. Between 1999 and 2002, workers who invested everything in stocks saw replacement rates fall 53 percentage points, while workers who invested half their savings in bonds saw replacement rates fall only 18 percentage points. Those who invested all their savings in bonds saw the replacement rate fall just 0.1 percentage point. Of course, workers who opt for a low-risk investment strategy will also receive a lower replacement rate on average than they would obtain if they invested all their savings in equities. Whereas the average replacement rate under a $100 \%$ stock investment strategy is $40 \%$, the average under the $50 \%$ stock / $50 \%$ bond strategy is only $24 \%$. Under the $100 \%$ government bond strategy, the average is just 14\%. Figure 5 emphasizes the trade-off workers face between good returns on their retirement savings and uncertainty over the value of their nest eggs as they approach retirement. A worker's retirement income is more predictable and less risky if funds are invested solely or mainly in very safe assets, but retirement income is almost certain to be considerably lower. In many years, workers who adopted the low-risk investment strategy obtained a much 
lower real rate of return on their individual account savings than they would have obtained on U.S. social security contributions.

Figure 5.

Replacement rate obtained from personal account savings of workers who invest in alternative portfolios and contribute $4 \%$ of annual salary over a 40 -year career

Replacement rate

(Annuity / Final wage)

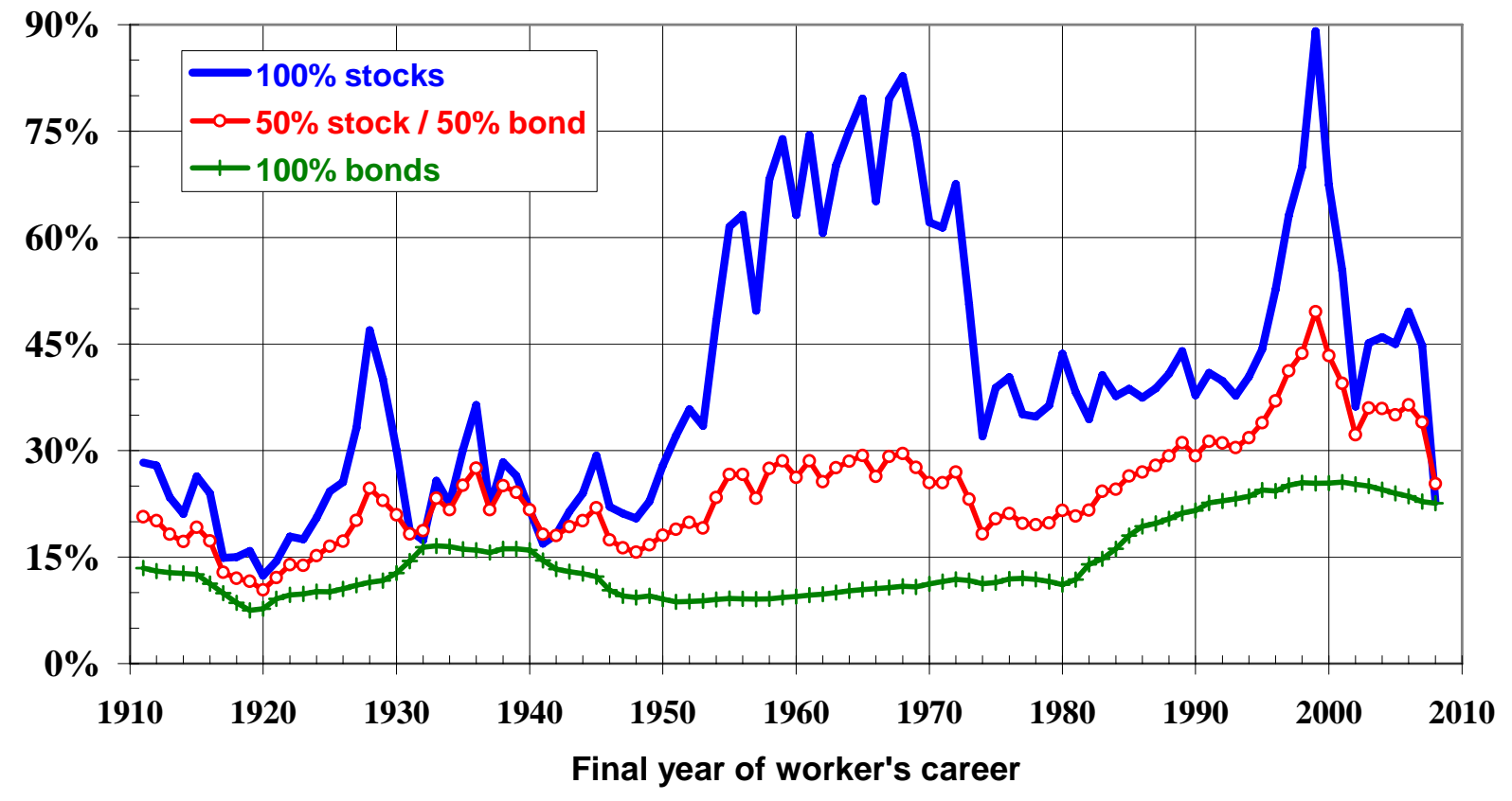

Source: Author's calculations as explained in text.

Besides investing in very safe assets, there are a couple of other strategies DC-covered workers can follow to reduce the uncertainty of their retirement incomes. One strategy is to begin purchasing annuities before reaching retirement and to buy a sequence of annuities over a number of years. This reduces the risk that all of the worker's funds will be converted to annuities when asset prices are exceptionally low or annuity prices are exceptionally high. In an earlier paper, I looked at the success of this strategy in reducing the variability of workers' initial replacement rates (Burtless 2002). Workers who purchased annuities in annual installments beginning five years before retirement were able to reduce the standard deviation of initial replacement rates by about one-sixth compared with workers who converted all of their savings at retirement. For workers who invest heavily in stocks before converting to an annuity, this 
strategy also reduces the expected return on lifetime savings, because assets are held as relatively safe, low-return annuities for a greater percentage of the worker's career.

Another investment strategy, popularized by financial advisors and mutual fund companies, is to shift gradually from a portfolio that is dominated by high-risk, high-return assets early in a career to a portfolio that is dominated by low-risk, low-return assets near the age of expected retirement (Canner, Mankiw, and Weil 1997). Judging by the portfolio descriptions provided by mutual fund companies, there is no agreement on how this portfolio shift should be accomplished. Figure 6 shows the portfolio allocation to equities (foreign and domestic) in six target-retirement-date funds, with the percent allocation plotted as a function of the number of years until a worker's expected retirement age. The average allocation in the six funds is indicated in the chart, as are the allocations in two funds with major differences in portfolio allocations. All the fund managers agree that equities should account for a declining percentage of worker assets as retirement approaches, but they do not agree on the starting and ending allocations or the rate at which equity investments should be exchanged for safe assets.

\section{Figure 6.}

\section{Percent of portfolio allocated to domestic and international equities, by years to retirement, in six target-date mutual funds}

\section{Percent of investment portfolio}

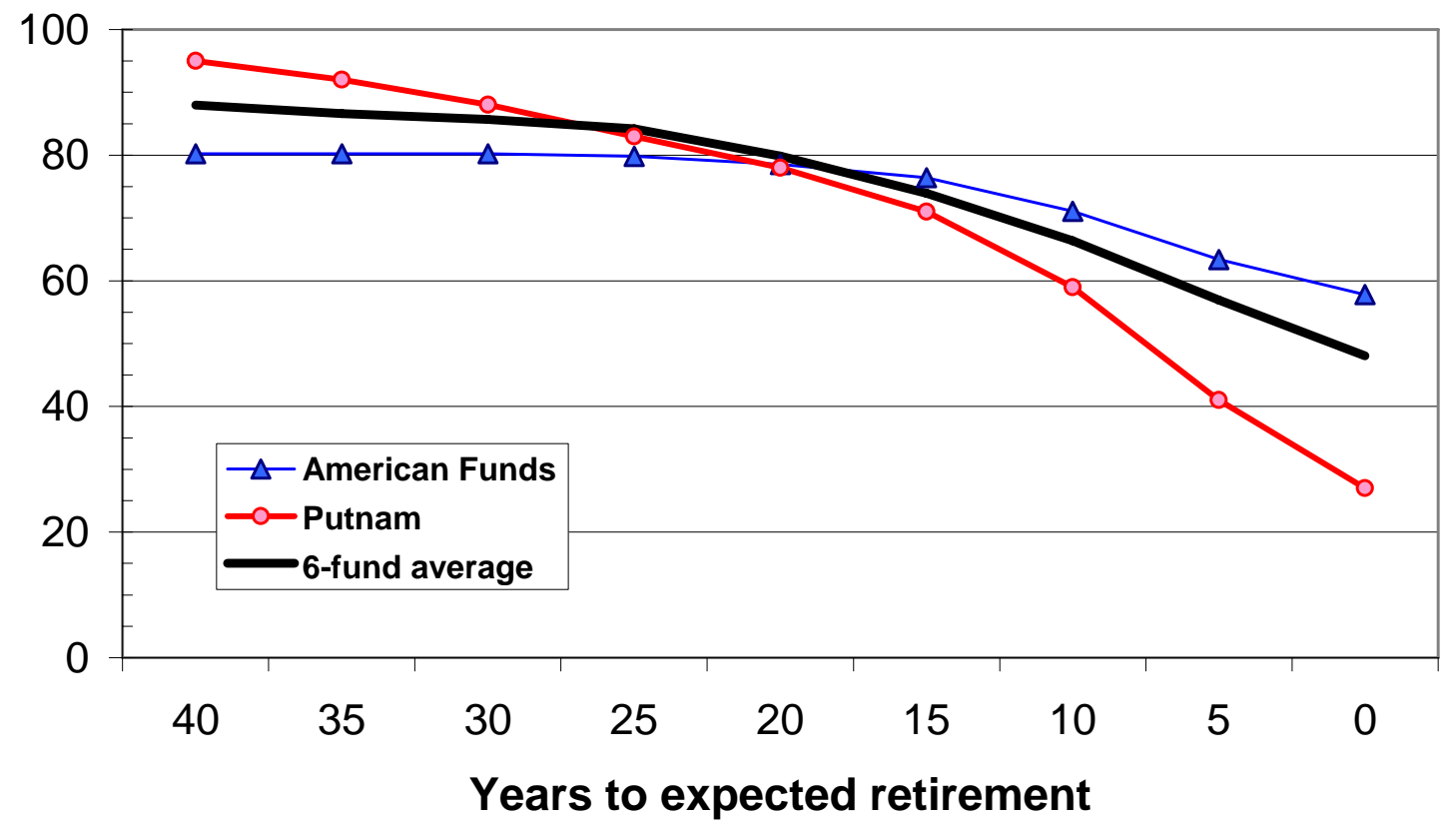

Sources: Author's calculations based on mutual fund descriptions provided by American Century, American Funds, Fidelity Funds, Putnam, TIAA-CREF, T. Rowe Price, and Vanguard. 
Robert Shiller has also proposed a life-cycle portfolio allocation for retirement savers (Shiller 2005). Under his proposal workers below age 29 would invest 85\% of their savings in equities and this percentage would fall steadily to $15 \%$ of the portfolio by age 60 . The remainder of the portfolio would be invested equally in long government bonds and safe commercial shortterm securities. Given the heavy allocation to safe assets, the Shiller portfolio exposes retirement savers to less risk than the target-date portfolios favored by most mutual fund companies. Figure 7 compares the historical replacement rates that would have been obtained under the Shiller target-date portfolio with the replacement rates obtainable under a 50-50 stock-bond portfolio. The proposed Shiller portfolio produces less variation in replacement rates, though much of the reduction in variance occurs because the portfolio is less likely to produce very high replacement rates.

\section{Figure 7.}

\section{Replacement rates obtained from personal account savings of workers who invest in two moderate-risk portfolios, workers retiring in 1911-2008}

\section{Replacement rate}

(Annuity / Final wage)

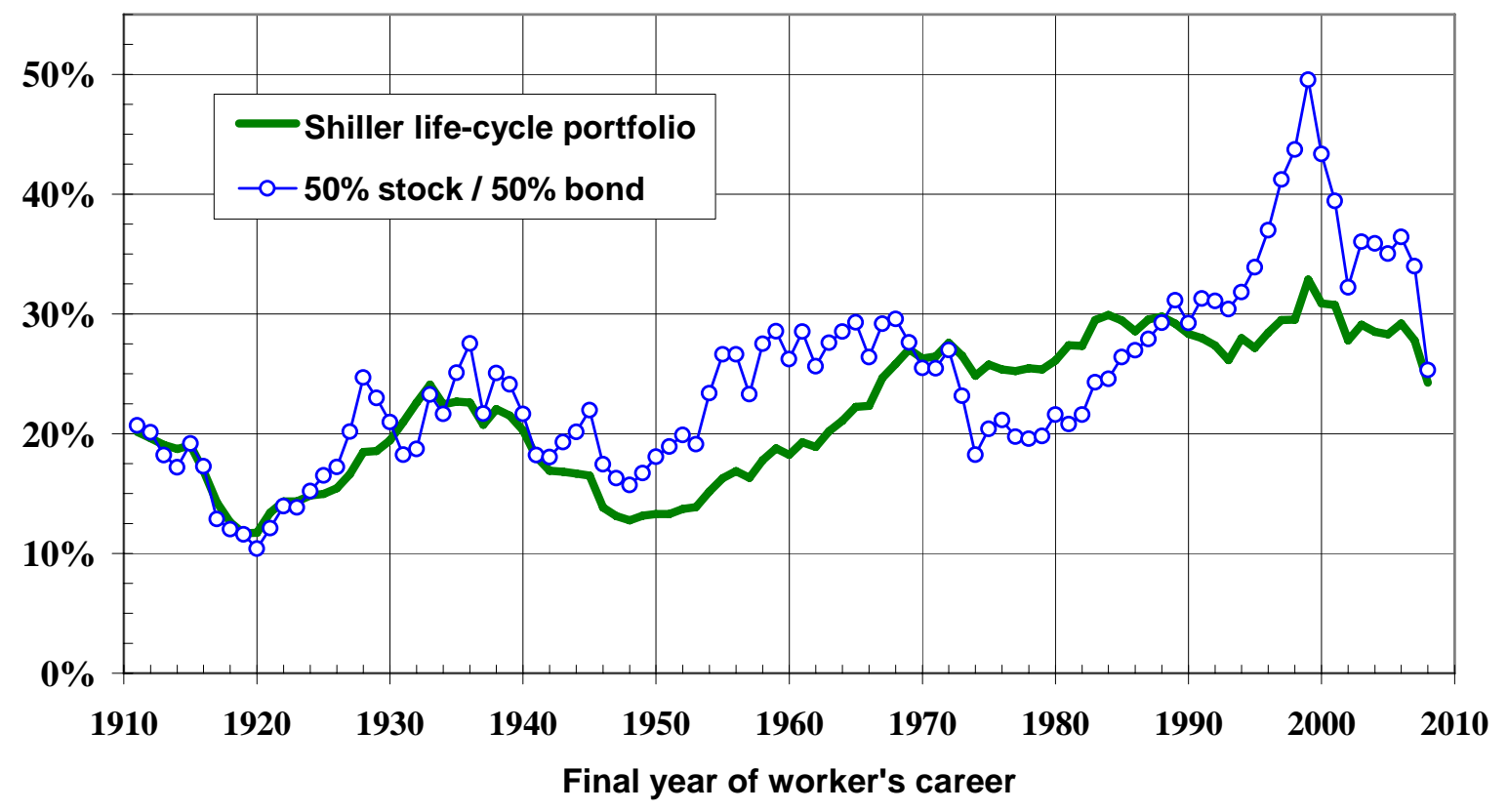

Source: Author's calculations as explained in text. 
Figure 8.

Mean and standard deviation of replacement rates obtained under alternative investment strategies, based on hypothetical returns of workers retiring 1911-2008

Average replacement rate (98 hypothetical workers)

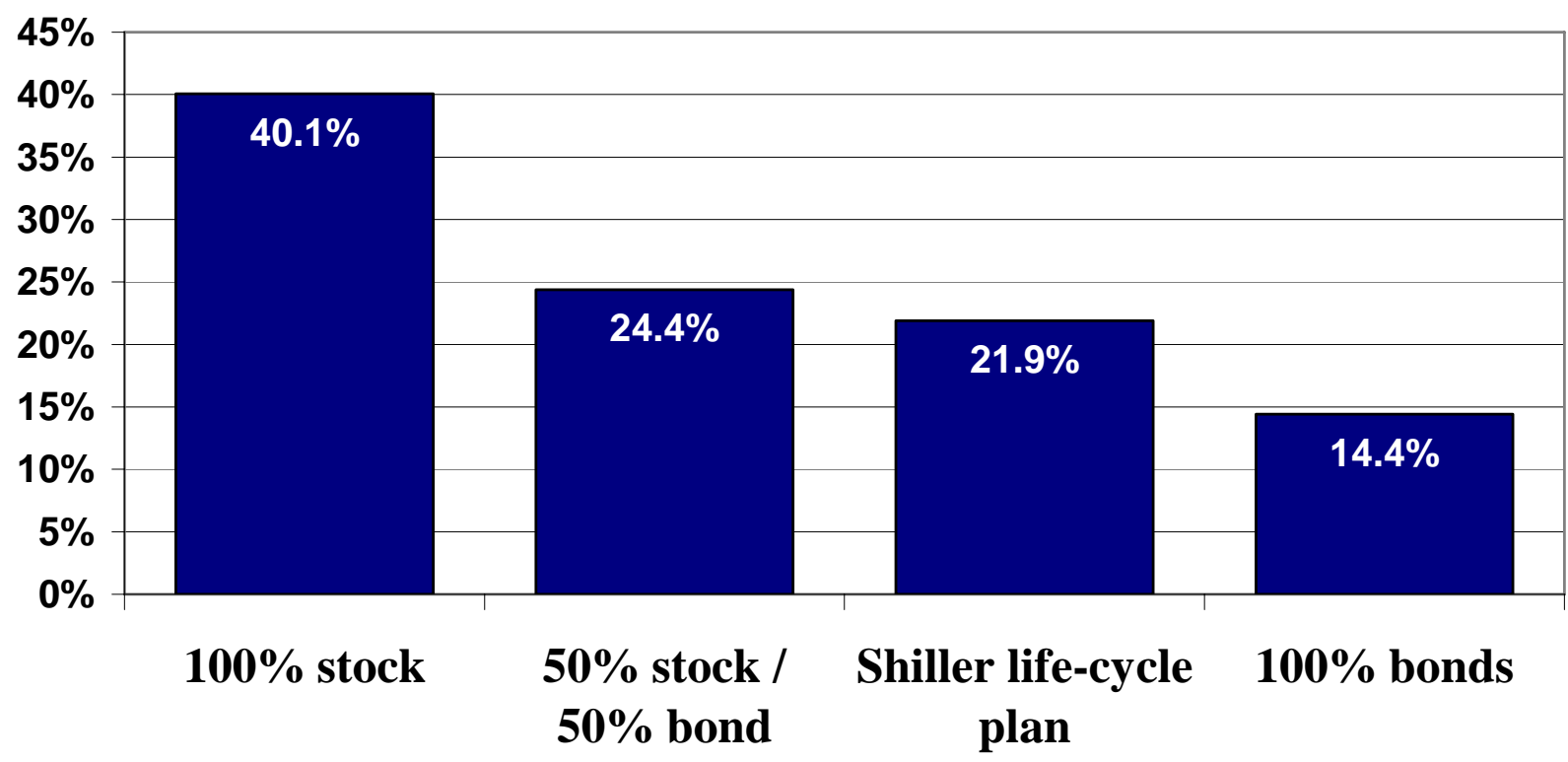

Standard deviation of replacement rates (98 hypothetical workers)

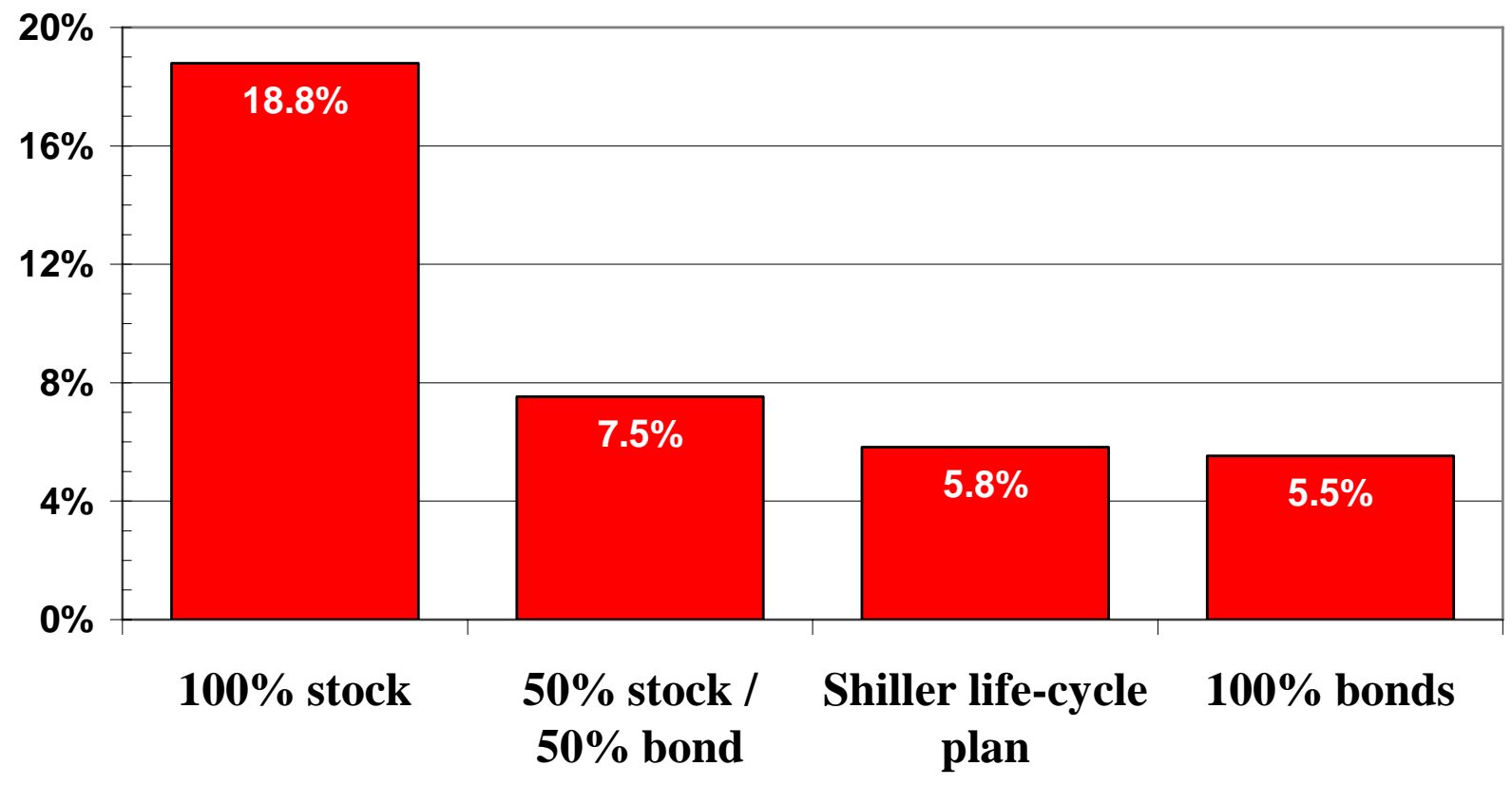

Note: Replacement rates calculated at assumed retirement age (62) for 98 hypothetical workers retiring at the end of 1911-2008. The assumed contribution rate is $4 \%$ of each worker's annual salary.

Source: Author's calculations as explained in text. 
The mean and standard deviation of pension replacement rates under alternative investment strategies are displayed in Figure 8. Not surprisingly, both the mean and the standard deviation are highest under an investment strategy that places $100 \%$ of the portfolio in U.S. equities. The lowest expected replacement rate and standard deviation are obtained under an investment strategy that places $100 \%$ of assets in long government bonds. The reduced variability of pension outcomes is obtained at considerable cost, however. The average replacement rate under a $100 \%$ bond investment strategy is almost two-thirds lower than the mean replacement rate when all retirement savings are invested in stocks. The other two portfolios show considerably less variability in replacement rates than the all-stock investment strategy. The target-age portfolio recommended by Shiller yields only slightly more variability than the all-bond portfolio, yet the mean replacement rate is more than half again larger than the average replacement rate under the all-bond investment strategy. Thus, in comparison with the all-bond portfolio, the Shiller investment strategy has a major advantage.

It is interesting to compare the impacts of recent stock market downturns on replacement rates under the four investment strategies. Table 1 shows how replacement rates differed for workers retiring in four recent years, 1999, 2002, 2007, and 2008. The first and third of these years represent the peaks of recent bull markets; the second and fourth years show the aftermath of a market crash. For workers investing half or all of their late-career savings in the stock market, the equity price decline brought sharp declines in expected pensions. Workers who invested all of their savings in long government bonds were almost unaffected by the market turmoil.

The uncertainty of private account pensions is understated in the replacement rate charts. The calculations do not take account of the effects of inflation in the years after a worker retires. In periods of high inflation, such as the 1940s, the 1970s, and the early 1980s, U.S. inflation was high and erratic. Social security benefits are adjusted upward to reflect changes in prices, sparing pensioners from the adverse effects of unexpected inflation. Workers with private pensions or annuities do not receive this kind of inflation protection. As a result, private pensioners experience big drops in the purchasing power of their annuities when prices rise unexpectedly. Although a number of countries make inflation-protected annuities available to private investors, such annuities are still difficult or impossible to obtain in most countries, including the United States. 


\section{Table 1.}

\section{Replacement rates before and after recent stock market declines under alternative investment strategies}

\begin{tabular}{|c|c|c|c|c|}
\hline \multirow[b]{2}{*}{$\begin{array}{c}\text { Retirement } \\
\text { year }\end{array}$} & \multicolumn{4}{|c|}{ Investment strategy } \\
\hline & $\begin{array}{l}\text { 100\% Stock } \\
\text { portfolio }\end{array}$ & $\begin{array}{l}50 \% \text { Stock / } \\
50 \% \text { Bond }\end{array}$ & $\begin{array}{c}\text { Shiller life- } \\
\text { cycle portfolio }\end{array}$ & $\begin{array}{l}100 \% \text { Bond } \\
\text { portfolio }\end{array}$ \\
\hline 1999 & 89.1 & 49.6 & 32.9 & 25.4 \\
\hline 2002 & 36.2 & 32.2 & 27.8 & 25.2 \\
\hline Difference & -52.9 & -17.3 & -5.1 & -0.1 \\
\hline 2007 & 44.8 & 34.0 & 27.8 & 22.8 \\
\hline 2008 & 22.8 & 25.3 & 24.3 & 22.6 \\
\hline Difference & -22.0 & -8.7 & -3.5 & -0.2 \\
\hline
\end{tabular}

Source: Author's calculations as explained in text.

\section{Investor psychology}

Investor psychology poses a second kind of risk that is not reflected in the charts. All the calculations are based on the assumption that workers follow a disciplined and consistent investment strategy throughout their careers. Research shows that many ordinary investors are neither consistent nor disciplined in their portfolio choices. They over-invest in assets that have performed strongly in the recent past, and they sell assets after a persistent or sharp fall in prices. These tendencies mean that many ordinary investors are inclined to buy assets when their price is high and sell them after their price has declined. Workers who make this kind of investment mistake will earn lower returns than the returns shown in the charts. The risk that workers might choose a bad investment strategy does not arise in current social security programs. Public social security provides a minimally adequate pension for nearly all workers who make contributions over a full career, regardless of the worker's investment expertise.

A retirement system that relies on workers to make their own decisions about retirement saving and investment would work well if workers make these decisions competently. The policy is riskier when a large fraction of workers bases saving and investment decisions on incomplete or faulty information, short time horizons, and bad reasoning. Private DC pension plans may 
require workers to assume more responsibility to save for retirement and to plan the timing of asset withdrawal after they retire. Nearly all such retirement plans require workers to allocate their pension savings across different investment options. If a nation relies heavily on workerdirected and privately managed DC accounts, it should be confident that most workers will make good decisions. Serious planning errors, either when the worker is employed or after she retires, can lead to serious hardship if the worker's error is a big one. By the time a retired worker discovers she has saved too little or has invested unwisely, she may have little opportunity to undo the mistake by increasing her saving rate, changing her portfolio, or going back to work.

Workers who elect or are required to set aside part of their wages in a private retirement account must ordinarily decide how to invest their savings. How good a job do they do? All analyses of investor behavior in employer-sponsored DC pension plans show that American workers trade very little, almost certainly too little. Few 401(k) participants exchange one kind of asset for another, and it is uncommon for workers to reallocate their new contributions among the investment alternatives available to them (Agnew, Balduzzi, and Sundén 2003; and Ameriks and Zeldes 2004). In a 10-year panel of observations in a large DC pension fund, Ameriks and Zeldes found that only 53\% of workers made any change in their allocation of new contributions and only $27 \%$ made a change to the allocation of assets already held in their accounts. This means that most workers' portfolio allocations change over time in response to realized returns on the different assets held in their portfolios. For example, workers who consistently allocate half of their new contributions to a diversified equity fund and half to a bond fund will see the stock-bond allocation of their portfolio vary widely over time if the relative returns on stocks and bonds differ. In the 1990s, stock returns were much higher than bond returns, so savers who failed to rebalance their portfolios ended the decade with a much higher proportion of their savings in stocks and a much smaller proportion in bonds. Most investment advisors recommend that savers rebalance their portfolios about once a year in order to maintain the risk profile of their holdings, but very few retirement savers follow this advice. All of the replacement rate calculations in Figures $4-8$ assume workers consistently rebalance their portfolios. Those who do not rebalance usually face unnecessary volatility in the lifetime returns on their portfolio.

A serious problem for most worker investors is lack of financial knowledge. A 1995 survey of U.S. mutual fund purchasers found that more than one-quarter were unaware that it is possible to lose money on investments held in a bond mutual fund. Only a minority of investors 
reported knowing the cost of owning the mutual funds in their portfolio. An even smaller percentage knew that higher fund expenses were likely to reduce investors' net returns. About one investor in five thought higher fund expenses would actually boost net returns (Alexander, Jones, and Nigro 1998). Economists have found considerable evidence that workers who are not financially literate are much less likely to invest in stocks (van Rooij, Lusardi, and Alessie 2007). Unlike the well-informed and fully rational saver imagined in standard economics, many actual savers do not take the trouble to become informed about the pros and cons of different kinds of investments, though the payoff from doing so would be substantial. Poorly informed savers invest little or none of their retirement savings in equities and other risky assets, even though nearly all economists and financial planners think such investments should receive at least some weight in a sensible retirement portfolio.

Several findings about worker investment behavior raise questions about their capacity to align their portfolios with their long-term goals. Many workers allocate too much of their retirement savings to a single stock, and to a particularly risky one. An investment option open to many U.S. retirement savers is stock in the company where they work. According to Schlomo Benartzi (2001), about a quarter of American workers' discretionary retirement savings is invested in the stock of their employers. Many individual workers invest all or nearly all of their pension savings in their employer's stock. From the point of view of risk management, this is a dubious savings strategy. First, the risk of owning a single stock is much greater than that of holding a diversified portfolio, such as that offered by an equity mutual fund. Second, the future performance of an employer's stock is likely to be positively correlated with the worker's wage earnings. If a worker is laid off because his employer falls on hard times, the employer's share price will probably decline at the same time. It is hard to understand why financially savvy workers would want to compound the misfortune of job loss by losing most of their retirement savings at the same time.

Many workers show little evidence they have carefully weighed their investment options or made knowledgeable decisions about their saving allocation. A sizeable percentage of workers leaves contributions in the default investment option under their employer retirement plan (Choi, Laibson, and Madrian 2004). It is not credible that the funds are left untouched because the default allocation corresponds to the worker's optimal choice. Workers are equally likely to remain in the default option investment plan, regardless of whether it is a low-risk money market 
fund or a moderate-risk stock-bond hybrid fund. The risk-expected return characteristics of the two investment options are very different, so workers' persistence in remaining in the default option is explained by inertia or lack of knowledge rather than by the happy coincidence of worker preferences and the risk characteristics of the default option.

Finally, many investors are excessively swayed by the packaging of the investment choices offered to them. In principle, well-informed investors should select a portfolio of assets because its risk and expected return characteristics correspond closely to those they desire. In practice, some investors will prefer to invest in option B if it is presented as an intermediate alternative between options $\mathrm{A}$ and $\mathrm{C}$, but will instead choose option $\mathrm{C}$ when it is presented as the intermediate alternative between options B and D. If options B and C are both available on different menus of investment alternatives, investors should always prefer B over C or C over B, regardless of the risk and return characteristics of the other investment options on the menu. Careful experiments by Benartzi and Thaler (2002) show, however, that some workers' preferences are decisively affected by extreme and intermediate alternatives that are offered on the menu. Workers who know little about investment are apparently guided in their portfolio allocation by factors that should be irrelevant to their decision.

Many proposals to privatize social security rest on the theory that workers will make informed and sensible choices if offered complete freedom to choose their retirement age, saving rate, and investment strategy. Under this assumption, popular with professors of economics and finance, workers select their retirement age and lifetime saving plan based on a farsighted evaluation of the potential risks and rewards of different retirement and saving options. This assumption is probably valid for some workers but is unlikely to be true for most of them. Many observers, including a few economists, are skeptical that workers think about retirement and savings in the farsighted and logical way just described. One reason that governments require workers to participate in social security, that companies provide pensions to their employees, and that unions pressure employers for more generous pensions is lack of confidence that workers will make sensible provision for old age on their own. The basic rationale for compulsory employer and government pensions is that it is better to organize retirement saving collectively and paternalistically rather than to rely on the unaided efforts of individual workers. 


\section{Policy implications}

A traditional defined-benefit pension helps solve a number of problems that most workers face as they prepare for retirement. First, the plan automatically sets aside a portion of current compensation as savings for retirement. Money in the account only becomes available when the worker is old or retired. Workers do not have to rely on their own judgment to select a retirement saving rate, nor do they have to rely on self-discipline to stick with the saving plan they adopt. Second, the money set aside in the retirement plan is managed by specialists who are knowledgeable about investing. Workers are not asked to rely on their own investment expertise, which may be limited. At least part of the investment risk is borne by employers or the government, reducing the variability of pensions that workers can expect to receive. Third, when workers reach the end of their careers, their retirement nest eggs are converted into monthly annuity payments that last for the remainder of their lives. Workers do not need to worry about living too long or spending their nest egg so quickly that they exhaust their retirement savings before they die.

A mandatory private DC pension solves one the three problems just mentioned by requiring workers to contribute a fraction of wages to a pension fund. If the mandatory pension also includes a provision requiring workers to convert their pension nest eggs to an annuity upon retirement it may solve a second problem as well. Workers will not have to worry about outliving their retirement savings. Workers are still left with the problem of highly uncertain pensions. They can of course adopt a very conservative investment strategy. Their pensions will be less variable but their expected rate of return on contributions will be much lower than they could have obtained under a collective retirement system, one in which investment risks are broadly shared across workers and taxpayers in several generations.

When workers in a DC plan are offered a variety of investment options in which to invest their savings, well-informed workers can in theory benefit by selecting an investment strategy that is closely aligned to their attitude toward expected return and risk. The question is, how large a percentage of workers is well-informed and disciplined? Optimists believe the percentage is high, and they are therefore more inclined to support a large role for publicly regulated but privately managed and worker-directed DC pension accounts. Pessimists are skeptical whether a large percentage of workers is competent to manage their own retirement 
savings. They are more inclined to favor public management or strong public regulation of investment choices and pension fund administration.

Last year's financial market turbulence should have reminded both policymakers and workers of the fact that even conservative investment strategies offer little assurance workers will reach old age with enough assets to pay for a comfortable retirement. To some degree the risks facing workers can be reduced through better financial education and the development of new retirement investment products. Although proponents of individual accounts continue to be confident that workers can purchase safe assets that will yield high rates of return, recent experience suggests that neither the value of financial assets nor their real return is predictable enough to assure a comfortable retirement income. Workers who follow identical investment strategies but who retire a few years apart can receive pensions that are startlingly unequal. By diversifying risks across generations and across different sources of pension funding, a sensibly designed public pension system can sharply reduce some of the risks inherent in a mainly private, capital-funded retirement system. 


\section{References}

Agnew, J., Balduzzi, P., and Sundén, A.E. 2003. "Portfolio Choice, Trading, and Returns in a Large 401(k) Plan.” American Economic Review 93(1) (March): 193-215.

Alexander, G. J., Jones, J. D., and Nigro, P. J. (1998) "Mutual Fund Shareholders: Characteristics, Investor Knowledge, and Sources of Information.” Financial Services Review, 7: 301-316.

Ameriks, J., and Zeldes, S.P. 2004. “How Do Household Portfolio Shares Vary with Age?” Working paper. New York: Columbia University Graduate School of Business.

Bebchuk, Lucian A. 2009. "Testimony on Compensation Structure and Systemic Risk," Committee on Financial Services, United States House of Representatives (June 11).

Bebchuk, Lucian A., and Jesse Fried. 2003. "Executive Compensation as an Agency Problem,” Journal of Economic Perspectives 17( 3): 71-92.

Benartzi, S. 2001. "Excessive Extrapolation and the Allocation of 401(k) Accounts to Company Stock.” Journal of Finance 56(5), 1747-64.

Benartzi, S., and Thaler, R.H. 2002. “How Much is Investor Autonomy Worth?” Journal of Finance 57(4): 1593-1616.

Burtless, Gary. 2002. “Social Security Privatization and Financial Market Risk: Lessons from U.S. Financial History,” T. Ihori and T. Tachibanaki, Social Security Reform in Advanced Countries. London and New York: Routledge.

. 2003. "What Do We Know about the Risk of Individual Account Pensions? Evidence from Industrial Countries.” American Economic Review 93(2) (May): 354-59.

. 2007. "International Investment for Retirement Savers: Historical Evidence on Risk and Returns,” Center for Retirement Research at Boston College Working Paper 2007-5 Chestnut Hill, MA: Boston College.

Canner, Niko, N. Gregory Mankiw, and David Weil. 1997. “An Asset Allocation Puzzle," American Economic Review 87(1) (March): 181-191.

Choi, J.J., Laibson, D., and Madrian, B.C. 2004. "Plan Design and 401(k) Savings Outcomes.” National Tax Journal 57 (June): 275-98.

Clingman, Michael, Orlo Nichols, and Chris Chaplain. 2008. Illustrative Benefits for Retired Workers, Disabled Workers, and Survivors Scheduled Under Current Law. Actuarial Note. Baltimore, MD: Office of the Chief Actuary, U.S. Social Security Administration.

Holzmann, Robert and Joseph E. Stiglitz (eds.). 2001. New Ideas about Old Age Security: Toward Sustainable Pension Systems in the 21st Century. Washington, DC: World Bank.

Orszag, Peter R., and Joseph E. Stiglitz. 2001. "Rethinking Pension Reform: Ten Myths about Social Security Systems.” In Robert Holtzman and Joseph E. Stiglitz (eds.). New Ideas about Old Age Security: Toward Sustainable Pension Systems in the 21st Century. Washington, DC: World Bank. 
Shiller, Robert J. 2005. "The Life-Cycle Personal Accounts Proposal for Social Security: An Evaluation.” NBER Working Paper No. 11300. Cambridge, MA.: National Bureau of Economic Research.

van Rooij, M., Lusardi, A., and Alessie, R. 2007. "Financial Literacy and Stock Market Participation." NBER Working Paper 13565. Cambridge, MA: National Bureau of Economic Research.

World Bank. 1994. Averting the Old-Age Crisis: Policies to Protect the Old and Promote Growth. New York: Oxford University Press. 


\section{CESifo Working Paper Series}

for full list see www.cesifo-group.org/wp

(address: Poschingerstr. 5, 81679 Munich, Germany, office@cesifo.de)

2673 Vivek Ghosal, Business Strategy and Firm Reorganization under Changing Market Conditions, June 2009

2674 Francesco Menoncin and Paolo M. Panteghini, Retrospective Capital Gains Taxation in the Real World, June 2009

2675 Thomas Hemmelgarn and Gaëtan Nicodème, Tax Co-ordination in Europe: Assessing the First Years of the EU-Savings Taxation Directive, June 2009

2676 Oliver Himmler, The Effects of School Competition on Academic Achievement and Grading Standards, June 2009

2677 Rolf Golombek and Michael Hoel, International Cooperation on Climate-Friendly Technologies, June 2009

2678 Martin Cave and Matthew Corkery, Regulation and Barriers to Trade in Telecommunications Services in the European Union, June 2009

2679 Costas Arkolakis, A Unified Theory of Firm Selection and Growth, June 2009

2680 Michelle R. Garfinkel, Stergios Skaperdas and Constantinos Syropoulos, International Trade and Transnational Insecurity: How Comparative Advantage and Power are Jointly Determined, June 2009

2681 Marcelo Resende, Capital Structure and Regulation in U.S. Local Telephony: An Exploratory Econometric Study; June 2009

2682 Marc Gronwald and Janina Ketterer, Evaluating Emission Trading as a Policy Tool Evidence from Conditional Jump Models, June 2009

2683 Stephan O. Hornig, Horst Rottmann and Rüdiger Wapler, Information Asymmetry, Education Signals and the Case of Ethnic and Native Germans, June 2009

2684 Benoit Dostie and Rajshri Jayaraman, The Effect of Adversity on Process Innovations and Managerial Incentives, June 2009

2685 Peter Egger, Christian Keuschnigg and Hannes Winner, Incorporation and Taxation: Theory and Firm-level Evidence, June 2009

2686 Chrysovalantou Milliou and Emmanuel Petrakis, Timing of Technology Adoption and Product Market Competition, June 2009

2687 Hans Degryse, Frank de Jong and Jérémie Lefebvre, An Empirical Analysis of Legal Insider Trading in the Netherlands, June 2009 
2688 Subhasish M. Chowdhury, Dan Kovenock and Roman M. Sheremeta, An Experimental Investigation of Colonel Blotto Games, June 2009

2689 Alexander Chudik, M. Hashem Pesaran and Elisa Tosetti, Weak and Strong Cross Section Dependence and Estimation of Large Panels, June 2009

2690 Mohamed El Hedi Arouri and Christophe Rault, On the Influence of Oil Prices on Stock Markets: Evidence from Panel Analysis in GCC Countries, June 2009

2691 Lars P. Feld and Christoph A. Schaltegger, Political Stability and Fiscal Policy - Time Series Evidence for the Swiss Federal Level since 1849, June 2009

2692 Michael Funke and Marc Gronwald, A Convex Hull Approach to Counterfactual Analysis of Trade Openness and Growth, June 2009

2693 Patricia Funk and Christina Gathmann, Does Direct Democracy Reduce the Size of Government? New Evidence from Historical Data, 1890-2000, June 2009

2694 Kirsten Wandschneider and Nikolaus Wolf, Shooting on a Moving Target: Explaining European Bank Rates during the Interwar Period, June 2009

2695 J. Atsu Amegashie, Third-Party Intervention in Conflicts and the Indirect Samaritan's Dilemma, June 2009

2696 Enrico Spolaore and Romain Wacziarg, War and Relatedness, June 2009

2697 Steven Brakman, Charles van Marrewijk and Arjen van Witteloostuijn, Market Liberalization in the European Natural Gas Market - the Importance of Capacity Constraints and Efficiency Differences, July 2009

2698 Huifang Tian, John Whalley and Yuezhou Cai, Trade Sanctions, Financial Transfers and BRIC's Participation in Global Climate Change Negotiations, July 2009

2699 Axel Dreher and Justina A. V. Fischer, Government Decentralization as a Disincentive for Transnational Terror? An Empirical Analysis, July 2009

2700 Balázs Égert, Tomasz Koźluk and Douglas Sutherland, Infrastructure and Growth: Empirical Evidence, July 2009

2701 Felix Bierbrauer, Optimal Income Taxation and Public Goods Provision in a Large Economy with Aggregate Uncertainty, July 2009

2702 Marc Gronwald, Investigating the U.S. Oil-Macroeconomy Nexus using Rolling Impulse Responses, July 2009

2703 Ali Bayar and Bram Smeets, Government Deficits in the European Union: An Analysis of Entry and Exit Dynamics, July 2009

2704 Stergios Skaperdas, The Costs of Organized Violence: A Review of the Evidence, July 2009 
2705 António Afonso and Christophe Rault, Spend-and-tax: A Panel Data Investigation for the EU, July 2009

2706 Bruno S. Frey, Punishment - and beyond, July 2009

2707 Michael Melvin and Mark P. Taylor, The Crisis in the Foreign Exchange Market, July 2009

2708 Firouz Gahvari, Friedman Rule in a Model with Endogenous Growth and Cash-inadvance Constraint, July 2009

2709 Jon H. Fiva and Gisle James Natvik, Do Re-election Probabilities Influence Public Investment?, July 2009

2710 Jarko Fidrmuc and Iikka Korhonen, The Impact of the Global Financial Crisis on Business Cycles in Asian Emerging Economies, July 2009

2711 J. Atsu Amegashie, Incomplete Property Rights and Overinvestment, July 2009

2712 Frank R. Lichtenberg, Response to Baker and Fugh-Berman's Critique of my Paper, "Why has Longevity Increased more in some States than in others?", July 2009

2713 Hans Jarle Kind, Tore Nilssen and Lars Sørgard, Business Models for Media Firms: Does Competition Matter for how they Raise Revenue?, July 2009

2714 Beatrix Brügger, Rafael Lalive and Josef Zweimüller, Does Culture Affect Unemployment? Evidence from the Röstigraben, July 2009

2715 Oliver Falck, Michael Fritsch and Stephan Heblich, Bohemians, Human Capital, and Regional Economic Growth, July 2009

2716 Wladimir Raymond, Pierre Mohnen, Franz Palm and Sybrand Schim van der Loeff, Innovative Sales, R\&D and Total Innovation Expenditures: Panel Evidence on their Dynamics, July 2009

2717 Ben J. Heijdra and Jochen O. Mierau, Annuity Market Imperfection, Retirement and Economic Growth, July 2009

2718 Kai Carstensen, Oliver Hülsewig and Timo Wollmershäuser, Price Dispersion in the Euro Area: The Case of a Symmetric Oil Price Shock, July 2009

2719 Katri Kosonen and Gaëtan Nicodème, The Role of Fiscal Instruments in Environmental Policy, July 2009

2720 Guglielmo Maria Caporale, Luca Onorante and Paolo Paesani, Inflation and Inflation Uncertainty in the Euro Area, July 2009

2721 Thushyanthan Baskaran and Lars P. Feld, Fiscal Decentralization and Economic Growth in OECD Countries: Is there a Relationship?, July 2009 
2722 Nadia Fiorino and Roberto Ricciuti, Interest Groups and Government Spending in Italy, 1876-1913, July 2009

2723 Andreas Wagener, Tax Competition, Relative Performance and Policy Imitation, July 2009

2724 Hans Fehr and Fabian Kindermann, Pension Funding and Individual Accounts in Economies with Life-cyclers and Myopes, July 2009

2725 Ernesto Reuben and Arno Riedl, Enforcement of Contribution Norms in Public Good Games with Heterogeneous Populations, July 2009

2726 Kurt Schmidheiny and Marius Brülhart, On the Equivalence of Location Choice Models: Conditional Logit, Nested Logit and Poisson, July 2009

2727 Bruno S. Frey, A Multiplicity of Approaches to Institutional Analysis. Applications to the Government and the Arts, July 2009

2728 Giovanni Villani, A Strategic R\&D Investment with Flexible Development Time in Real Option Game Analysis, July 2009

2729 Luca Di Corato and Michele Moretto, Investing in Biogas: Timing, Technological Choice and the Value of Flexibility from Inputs Mix, July 2009

2730 Gilad D. Aharonovitz, Nathan Skuza and Faysal Fahs, Can Integrity Replace Institutions? Theory and Evidence, July 2009

2731 Michele Moretto and Sergio Vergalli, Managing Migration through Conflicting Policies: an Option-theory Perspective, July 2009

2732 Volker Nitsch, Fly or Cry: Is Airport Noise Costly?, July 2009

2733 Francesco Cinnirella and Joachim Winter, Size Matters! Body Height and Labor Market Discrimination: A Cross-European Analysis, July 2009

2734 Samuel Bowles and Sandra Polanía Reyes, Economic Incentives and Social Preferences: A Preference-based Lucas Critique of Public Policy, July 2009

2735 Gary Burtless, Lessons of the Financial Crisis for the Design of National Pension Systems, July 2009 